\title{
The Development Of Islamic Pawnbroking In Malaysia, Application And Its Challenges
}

\author{
Nor Fadilah bt Bahari, ${ }^{1}$,Shafina bt Fisal, ${ }^{2}$, Wan Shahdila Shah bt Shahar, ${ }^{3}$, Hj Tajul Azli bin Shahadan' 4 \\ ${ }^{1,2,3}$ Lecturer, Department of Banking and Finance, Selangor International Islamic University College, Bandar Seri \\ Putra,43000 Kajang Selangor \\ ${ }^{4}$ Lecturer, Department of Management and Information Technology \\ Sultan Azlan Shah Islamic University College (KUISAS), Kuala Kangsar, 33000, Perak \\ ${ }^{1}$ norfadilah@ kuis.edu.my, ${ }^{2}$ shafina@ kuis.edu.my \\ wanshahdila@ kuis.edu.my, ${ }^{4}$ tajulazli @ kuisas.edu.my
}

\begin{abstract}
Islamic Pawn Broking industry, known as Ar Rahnu, have since received tremendous support in the Malaysian market, especially amongst micro, small and medium entrepreneurs. The pioneer of Ar Rahnu in Malaysia was Muassasah Gadaian Islam Terengganu(MGIT) introduced in 1992. This paper aims to provide a review on the development of Ar Rahnu and discuss on the application of Ar Rahnu in Bank Rakyat Malaysia Berhad. The study employs the previous studies and engages an interview session with the staff of Ar Rahnu Bank Rakyat. In the early stage of ArRahnu establishment, the demand was influenced by the Muslim societies to obtain financing based on the Shariah principle. Simultaneously, with the effort of the Malaysian government to

I. Introduction
\end{abstract}

The demand for pawn broking services witness increasing business in Malaysia due to the convenience of lending money or instant cash to the needy. The industry has grown significantly over the past years as pawn broking constitute a simple and easy method of financing, without the requirement to provide proof of income or other financial documents, and that customers only need to pledge their valuable assets such as gold as a form of collateral or security to the pawn shop.

Customers with low level income and small-sized entrepreneurs generally turn to pawnshop services for financing because financing facilities from financial institutions are mostly accessible to the most creditworthy borrowers that generally belong to middle and high income groups (Johari, Sanusi and Rais, 2007). The majority of the pawn broking customers were generally individuals who do not have access to a formal financial system, as the financial system tend to allocate credit to mainly the most creditworthy borrowers.

In the early stage of establishment, pawnshop businesses or known as collateral based lending business operate as a one promote the development of Islamic pawn broking industry, the demand for Ar-Rahnu services increase continuously. The industry has tremendously contributed to the Muslim economy because it plays an important role as a means of community service that fulfil the desperate needs of low income families. It also acts as a source of capital to small businesses that provides quick and easy source of financing as compared to loans from commercial banks. More importantly, this paper also attempts to highlight on the existing challenges of Ar Rahnu, with respect to its growth and development.

Keywords; Islamic pawn broking, Ar rahnu, application, challenges.

stop financial centre for their customers. Most pawnshops are privately owned and operated for the purpose of profit-making (Ismail, A. G., \& Ahmad, N. Z. (1997). At the end of 1991 about 194 conventional pawnshops operated in Malaysia under the supervison of Ministry of Local Government and housing(Skully, Michael T 1992). To date, both conventional and Islamic pawn broking in Malaysia are separately regulated under the Pawnbroker Act 1972 to ensure a smooth and healthy operation in the pawn broking industry. In term of legislation, the Islamic Pawnbroking system is subject to certain laws but not specific acts. For example Bank Kerjasama Rakyat Malaysia Berhad(Bank Rakyat) is subject to three different acts which are the bank Kerjasama Rakyat(M) Berhad Act 1978, Cooperatove Societies Act(1993) and Development Finance Institutions Act 2002 . Moreover, Bank rakyat has introduced separately the $\mathrm{Ar}$ Rahnu manual guidelines.

Conventional pawnshops had already taken place in Malaysia, which were mostly managed by the Malaysian Chinese community. They provided instant cash to customers who pawned their valuables to help their business or to support 
their needs. However, the conventional pawn shops imposed relatively high interest rates which is $24 \%$ perannum, and undertake usurious and exploitative activities, which indeed had oppressed and laid burden on the lower income groups. For these reasons, most customers shifted to Islamic pawn broking services (Razak, 2008). Abdul Razak (2011) conjectured that the operations of the conventional pawn broking business were not transparent in valuing the pawned goods and auctioning of the pawned goods was done without notifying the customers.

The system of charging interest implemented by conventional pawn broking and financial institutions had been criticized by the Muslim community due to the existence of the element riba in the contract, which increased the burden of the customers to repay the loan and may caused the pawner lose their property. The Muslim communities gradually became aware that conventional pawnshops did not meet the shariah of Islam.

The weaknesses of conventional pawn broking urged the establishment of Islamic pawn broking in Malaysia. In 1992, the establishment of Muassasah Gadaian Islam Terengganu (MGIT) was a starting point to the Islamic pawn broking in

\section{2.0 The Development of Ar Rahnu / Islamic Pawnshop in Malaysia}

Islamic pawnshop in Malaysia, normally known as Ar Rahnu, basically performs the same functions as the conventional pawn broking. The only difference is that Ar Rahnu operates and provides financing facilities based on the Islamic principles. Ar Rahnu is defined as a method of providing fund to a person who pawns her/his jewelries to a pawnshop or bank as a security. The Malaysian government initiated an Islamic pawn broking that can be accessed by the Muslim community in getting immediate cash or fund. Currently, Islamic pawnshops not only serve the Muslim community but also to other races in the country.

The pioneer of Islamic pawn broking was Muasasah Gadaian Islam Terengganu (MGIT), which was established in 1992 by the Terengganu State Islamic Affairs and Malay Customs. In the early stage of the establishment, MGIT played a vital role in the Muslim community especially for women and small businesses in providing instant cash and micro financing. The implementation of MGIT by Terengganu state also aimed to ensure that the Muslim communities in Terengganu were able to obtain financing according to Shariah principles and to evade them from conventional pawn broking. A recent study by Azizah O., et al. (2013), discovered that the total number of customers that pledged with MGIT from year 2007 until 2011 was 190,810 customers with 9 total numbers of outlet. Johari, Sanusi and Rais (2007) found that the main reasons customers
Malaysia. Demand by the Muslim community and customers in Terengganu state led to the implementation of MGIT. Presently, Islamic pawn broking in Malaysia has been growing tremendously due to the increasing number of Ar Rahnu outlets and financial institutions that take part in Islamic pawn broking industry.

After 23 years of implementation of Ar Rahnu in Malaysia, the Ar Rahnu industry had shown tremendous improvement which plays an important role in the economic development and social wealth of the country. In January 2011, the Star Online reported that the total number of pawnshops in Malaysia was around 276 across Malaysia. Currently the functions of Islamic pawn broking services have evolved to serve not only the poor or needy, but also to the middle class or high income group of customers. They visit the pawnshops to obtain quick cash to help their business or use the money to invest without being involved in stringent procedures like applying loans with the banks. Hence, this paper aims is to review the development and growth of Islamic pawn broking services in Malaysia and the application of Ar Rahnu scheme by Ar Rahnu Bank Rakyat. Apart from that, this paper also attempts to discuss the challenges faced by the Islamic pawn broking industry in Malaysia.

preferred to pawn with Islamic pawnshops was because of lower storage charges as compared to conventional pawnshops as practiced by Muasassah Gadaian Islam Terengganu (MGIT). MGIT had indeed played a vital role in the economic development of Terengganu.

The development of Islamic pawn broking continued with the establishment of Kedai Ar Rahnu (KAR) as a subsidiary to Permodalan Kelantan Berhad (PKB) in Mac 1992. Currently in year 2015, Kedai Ar Rahnu (KAR) operates 25 outlets around Malaysia including Sabah. The Islamic pawn broking industry in Malaysia progressed and thrived further with the Ministry of Finance introducing Ar Rahnu scheme through the collaboration of three institutions namely Bank Negara Malaysia, Yayasan Pembangunan Ekonomi Malaysia (YAPEIM) and Bank Kerjasama Rakyat Malaysia Berhad (Bank Rakyat) in August 1993, in which YAPEIM currently operates with 176 outlets around Malaysia including Sabah and Sarawak.

Initially, Bank Rakyat established Ar-Rahnu branches at Bandar Tun Razak, Mergong, Seremban, Butterworth, Muar and Kuala Terengganu via cooperation with YAPEIM. Later in 1975, Bank Rakyat set up RManagement to provide franchising opportunities under its Ar Rahnu X'Change brand name. Established in the market for over five decades, Bank 
Rakyat is the largest Islamic co-operative bank in Malaysia and currently in 2015 Bank Rakyat Ar Rahnu has grown to 146 outlets and Bank Rakyat X Change with 91 outlets operating all over the country. The Ar-Rahnu business recorded a $4.97 \%$ increase in revenue in 2013 of RM256,563,000 as compared to $4 \%$ in 2012 with RM247,701,000 of total revenue (Annual report Bank Rakyat,2013). With the long-standing experience in serving the market, this diligently enables the Bank to understand its customers' needs.

The Ar Rahnu industry further grew with Bank Islam entering the market which formerly commenced in 1997, followed by EON Bank in August 2002 and Bank Pertanian Malaysia in

\section{Principle and Application of Bank Kerjasama Rakyat Malaysia Berhad Ar Rahnu}

Ar Rahnu literally from the Arabic noun is derived from the word rahana which means either constancy and continuity, or holding and binding. Technically, rahn, which is also termed as pawning, mortgage, collateral, charge, lien and pledge, refers to taking a property as a security against a debt, whereby the secured property can be utilised to repay the debt in the case of non-payment.

Referring to the relative importance of the concept, Ar-Rahnu itself is the contract of Tabarru' or charitable contract where it is known to operate as the donation of money lending without any earning of profit by pledging the particular items as collateral. It does not require any financial obligation on the part of the creditor (murtahin) when the debtor (rahin) gives him the pawned object. In this case, Ar-Rahn is similar to the other voluntary charitable contracts such as gift

The foundations regarding the Ar rahnu are also mentioned in the following hadith;

"A'ishah narrated that: "The Prophet (p.b.u.h.) bought some food (on credit) from a Jew and he pawned his iron shield to him."
September 2002. Another innovative approach undertaken by Pos Malaysia with its banking partner Bank Muamalat was the launching of Islamic pawn broking business under the brand name Ar Rahnu@POS in 2012. To date, the majority of banks in Malaysia such as Affin Bank Berhad, RHB Bank Berhad, Agro Bank and others, are involved in providing Ar Rahnu schemes. A wider distribution of Ar Rahnu has to a certain extent helped to decrease the dependency on loan sharks by the customers. The increasing number of Islamic pawnshops in Malaysia is a manifestation of the increasing demand for Islamic pawn broking services and the main attraction for such services are basically the halal sources of financing facilities, easy loan approval procedures, and low safe-keeping charges as compared to conventional pawn broking services.

(hibah), simple loan, loan (qard), and deposit (wadi'ah).

The specialty of Ar Rahnu as compared to the conventional pawn broking, is that Ar Rahnu have special guidelines from Al Quran and As Sunnah in its operations to ensure the validity of the contract. Conventional pawn broking exist with the manmade rule and with the purpose of profit making in which contradict with the implementation of Ar Rahnu.

\section{Evidence from al-Qur'an;}

Allah (s.w.t.) says:

"If you are on a journey and cannot find a scribe, then use the receipt of pawn objects"

This verse clearly indicates the alternative means of documenting the debt in the absence of the scribe, i.e., via pawning. Although it was revealed in the context of travelling, the majority of jurists, except Mujahid and Zahiris, agree that rahn is also permissible at home, based on the Sunnah of the Prophet (p.b.u.h.) who permitted it without any restriction.

From the above evidences derived from al Quran and al Hadith, the application of Ar Rahnu is hence in accordance with the principle of Islam. Table 1 explains the pillars of Ar Rahnu contract. 
TABLE 1:

Pillars of Ar Rahnu principle.

$\begin{array}{ll}\text { Borrower(al rahin) } & \begin{array}{l}\text { A party that borrows money from another party by placing valuable asset as } \\ \text { collateral. }\end{array} \\ \text { Lender(al-murtahin) } & \begin{array}{l}\text { A party that lends money to another party and responsible for the safety of the } \\ \text { valuable asset pledged by the borrower. The contract should be accepted by the both } \\ \text { parties. }\end{array} \\ \text { Items pawned as collateral } \\ \text { Loan amount } & \begin{array}{l}\text { The amount of loan needed by the borrower } \\ \text { Agreement/ sighah }\end{array} \\ \end{array}$

It is mandatory for the application of Ar Rahnu to fulfill the above pillars. Appannan and Doris (2010) found that the operation for Islamic pawnshop transaction is quite similar

\section{Modus Operandi of Ar-Rahnu Bank Rakyat Malaysia} berhad.

Ar Rahnu Bank Rakyat provides services that are applicable to all community including non-Muslim customers. In Ar Rahnu with the conventional but the only difference is in the contractual terms (aqad) that is based on Islamic jurisprudence.

Bank Rakyat, gold is only permitted item to be pawned. In order to obtain loan from the Ar Rahnu Bank Rakyat, customers are required to adhere to the following requirements as described in Table 2.

TABLE 2:

The features of Ar Rahnu Bank Rakyat.

\begin{tabular}{|ll|}
\hline Features & Description \\
\hline Eligibility & Malaysian citizens \\
& $\begin{array}{l}\text { Permanent residents } \\
\text { Aged above 18 years old }\end{array}$ \\
\hline Pawning limit & $\begin{array}{l}\text { Minimum RM100.00 but for az zahab scheme minimum is RM10,001.00 } \\
\text { Maximum accumulative amount RM50,000@ RM 100,000 per day } \\
\text { Az zahab maximum amount RM100,000 }\end{array}$ \\
\hline Pawning period & 6 months + 6 months (extension period) \\
& $\begin{array}{l}\text { Maximum period until 18 months from the date } \\
\text { For azzahab scheme 6 months+6 months/ 3 years }\end{array}$ \\
\hline Pawn redemption & Can be made once or by installment before the due date \\
\hline
\end{tabular}

The application of Ar Rahnu Bank Rakyat involved three Shariah concepts;

Qardh: An interest free loan. Generally, the customer is required to pay only the principal amount borrowed. Under this product, the bank will grant loan to the customers and the customers will pledge his/ her gold jewellery as surety for the said loan. The same amount is to be repaid to the bank by the customer on maturity or on demand.

Ujrah: This refers to charge or fee for services provided. Under this product, the bank will charge a reasonable safekeeping fee for keeping the gold or jewellery in a safe condition during the loan tenure. Wadiah Yad Dhamanah: It refers to an agreement for placement of assets or money to another person for safekeeping. The bank promises to keep the gold or jewellery in its custody during the loan period and the bank shall be responsible to replace the gold or jewellery to the customer should the gold jewelry goes missing or stolen. If it is not due to the bank's negligence, the bank is however will not be responsible to bear the cost.

The pawned items will be valued by the bank officer to determine the suitable loan size for the customers. The valuation is based on the purity of the gold item and will be 
valued at prevailing marjet price. For Bank Rakyat Ar Rahnu, the amount of loan will be given to the new customers up till $65 \%$ of the gold value pawned, while existing customers $75 \%$. The gold will be valued at the prevailing market price and the maturity of loan in Bank Rakyat Ar Rahnu is within 6 months period, which can be extended to a maximum period of 18 months. Furthermore, the bank will impose safe keeping fees to the customer as shown in Table 3. The safe keeping fees is calculated based on the value of gold. In practice, the safekeeping fees will be charged differently by each of Islamic pawn brokers. The comparative rate of safe keeping fees among the Islamic pawn brokers as shown in Table 4.

\section{TABLE 3:}

Safe keeping fees/Storage fees charged by Ar Rahnu Bank Rakyat

\begin{tabular}{|c|c|c|c|}
\hline Types of scheme & $\begin{array}{l}\text { Limit of financing } \\
\text { amount(RM) }\end{array}$ & Margin of financing & $\begin{array}{l}\text { Safe keeping fees for each } \\
\text { RM100 over the value of } \\
\text { marhun a month (RM) }\end{array}$ \\
\hline \multirow[t]{4}{*}{ Ar rahnu } & Up to $1,000.00$ & $\begin{array}{l}65 \% \quad \text { (value for new } \\
\text { customers) }\end{array}$ & 0.65 \\
\hline & & $\begin{array}{l}70 \% \text { (value for existing } \\
\text { customers) }\end{array}$ & 0.75 \\
\hline & $>1,0001.00-10,000,00$ & $\begin{array}{l}65 \% \quad \text { (value for new } \\
\text { customers) }\end{array}$ & 0.65 \\
\hline & & $\begin{array}{l}75 \% \text { (value for existing } \\
\text { customers) }\end{array}$ & 0.75 \\
\hline
\end{tabular}


TABLE 4 :

Comparative rate of Safe keeping Fees among several Islamic pawn brokers in

Malaysia

\begin{tabular}{|c|c|c|c|}
\hline Institutions & Value of Marhun & $\begin{array}{l}\text { Margin of } \\
\text { financing }\end{array}$ & $\begin{array}{l}\text { Safe keeping fees for each RM100 over } \\
\text { the value of marhun a month (RM) }\end{array}$ \\
\hline Bank Rakyat & Up to 1000 & $\begin{array}{l}65 \% \\
75 \%\end{array}$ & $\begin{array}{c}0.65 \\
0.75 \text { (existing customer) }\end{array}$ \\
\hline RHB Ar Rahnu & $\begin{array}{l}100-2,000 \\
2,001-5,000 \\
5,000 \text { and above }\end{array}$ & $\begin{array}{l}70 \% \\
75 \%\end{array}$ & $\begin{array}{l}0.65 \\
0.75 \\
0.80\end{array}$ \\
\hline YAPEIM & $\begin{array}{l}\text { special rate } \\
\text { RM720 and below } \\
\text { RM721.00-RM2000 } \\
\text { RM2001 and above }\end{array}$ & $<65 \%$ & $\begin{array}{l}\text { RM0.10 } \\
\text { RM0.50 } \\
\text { RM0.65 } \\
\text { RM0.75 }\end{array}$ \\
\hline MGIT & $\begin{array}{l}>\text { RM1000 } \\
\text { RM1001- RM } 3000 \\
\text { RM3001-RM5000 } \\
\text { RM5000-RM10000 } \\
\text { RM10000 above }\end{array}$ & & $\begin{array}{c}\text { Free } \\
\text { RM0.50 } \\
\text { RM0.60 } \\
\text { RM0.70 } \\
\text { RM0.75 }\end{array}$ \\
\hline $\begin{array}{l}\text { Ar Rahnu } \\
\text { Kelantan(KAR) }\end{array}$ & RM $100<$ above & $<60 \%$ & RM 0.50 \\
\hline Bank Islam & $\begin{array}{l}\text { Up to RM500 } \\
\text { RM501- RM } 2500 \\
\text { More than RM2500 }\end{array}$ & $<70 \%$ & $\begin{array}{l}\text { RM0.60 } \\
\text { RM0.70 } \\
\text { RM } 0.80\end{array}$ \\
\hline Agro Bank & $\begin{array}{l}\text { RM100-RM2000 } \\
2001-5000 \\
5,000 \text { above }\end{array}$ & $<70 \%$ & $\begin{array}{l}\text { RM0.50 } \\
\text { RM0.60 } \\
\text { RM } 0.75\end{array}$ \\
\hline Pos Malaysia & RM $100<$ above & $<75 \%$ & $\begin{array}{l}\text { RM0.65 } \\
\text { RM0.75 }\end{array}$ \\
\hline
\end{tabular}

Sources: www.bankrakyat.com.my, www.bankislam.com.my/arrahnu, http://yapeim.net.my/ar-rahnuyapeim,www.agrobank.com.my,www.pos.com.my/arrahnu 
Sample calculation of safe keeping fees charge by Bank

Rakyat Ar Rahnu

Value of the jewellery : RM,1000

Loan amount : RM650(65\%)

Tenure $\quad: 6$ months@ 180 days

Calculation:

RM1000 x 0.65/100 x 12months x 180/365

Total safekeeping fees for 6 months $=$ RM38.47

The charged of safe keeping fees can be paid either in lumps sum during the aqad or on deferred basis. A receipt will be given to the customer as proof of transaction. The receipt states the customer's name and address, a description of the collateral, amount lent, maturity date and the amount that must be paid to redeem the assets.

\section{Challenges faced by Islamic Pawn Brokers in Malaysia}

The existence of Ar Rahnu industry plays a significant role in the economic development of Malaysia. Nevertheless, $\mathrm{Ar}$ Rahnu industry players need to address

several challenges in their operations in order to sustain in this challenging market place. Among the prominent challenges to the Islamic pawn broking is the higher margin of financing offered by the conventional pawn broking firms. From the previous study by Azila (2011), the author observed that with respect to conventional pawn broking, customers could negotiate the loan amount with the officers in relation to the perceived value of the collateral. In some conditions, the amount of loan obtained could be up to $85 \%$ to $90 \%$ of the jewellery value. In contrast with the Ar Rahnu, majority of the operators provide a lower margin of financing of about $65 \%$ to $80 \%$ from the value of marhun. This is one of the main reasons why most customers still resort to conventional pawn brokers or illegal sources for financing.

Secondly, lack of knowledge and awareness among the society regarding the operations of Ar Rahnu also renders a challenge to the industry, particularly in their effort to raise its market share vis a vis other forms of financing. Most customers are reluctant to use Islamic pawnshop services because it is perceived by the society as products that are meant for the poor and small businesses (S.Hisham, etl. 2013). Similarly, Appannan and Doris (2011) found that majority of the Indian community in Sungai Petani was not aware of the existence of Ar Rahnu scheme. This is a challenge to Ar Rahnu operators, with the implication that Ar Rahnu operators should increase their advertisement and marketing programs so as to increase awareness to all customers, irrespective of race in Malaysia.
In the case of default by the customer to redeem the marhun within a specified predetermined period, or the customer not able to settle the safekeeping fees, the loan can be extended to the maximum period as agreed by the bank. At the end of the period, a notice within 14 days will be given to the customers. If there is no action taken by the customer, bank has the right to auction the articles. Notice of auction will be sent to the customer. Proceeds from the auction will be used to pay the loan, safe keeping fees and other costs involved such as cost incurred during the auctioning process. If the pawned item is sold with surplus in the auction, the customer is entitled to that surplus. Nevertheless if no claim for the surplus is made, or in case the customer cannot be located, the surplus will be forwarded to the Baitulmal from which the customer is entitled to make future claims. In contrast with the operations of conventional pawn broking, it has been reported that pawnbrokers do not return the surplus after the goods have been auctioned off (Azila,2011).

Furthermore S.A. Bashir Ahmad, Norudin Mansor et.al. (2012) suggest that the Islamic-based pawnshop must stress the importance of customer service in order to strengthen the customer base, in addition to "Syariah" view concern. They postulated that management practices was the most dominant factor that contribute towards customer acceptance of ArRahnu MAIDAM in Dungun. This is consistent with the findings of Mohammad, et. al. (2014) and Hanudin Amin (2011), which revealed that the factor of 'Shariah View' dominated the choices of the respondents as their preferences on the Ar-Rahnu scheme. Elements of "Al Quran and Sunnah" as a source of business" and operations based on the shariah compliance ranked in the top tenth place as important to the respondents. This proof that the Ar Rahnu operators must ensure their practice and operations does not contradict with Shariah rules and minimize the shariah issues a rise in their operation.

In addition service quality such staff competency in valuing the pawned items and facilities in the Ar Rahnu operation one of the issues raised by the customers. It is a challenge to the $\mathrm{Ar}$ Rahnu operators to improve the quality of management to ensure the customer satisfaction. According to Azizah O.etls.,(2012) services quality is one of prominent factor of customers satistaction. Suggested that, Ar Rahnu operators to provide a good facilities and improve the staff efficiency. Advisable Ar Rahnu operators must have their own Internal Shariah Legal Advisors to supervise the operation of $\mathrm{Ar}$ Rahnu to ensure the operations is accordance to Shariah principles.

Islamic pawnshop encourage to reconsider items that can be pawned by the customers. Imani Mokhtar etl. (2013) mention practically the assets that can be pledges at Islamic Pawn shop are only gold and jewelleries. Contrast with the operation of 
conventional pawn shop, pawned items can be in various forms such as jewellery, diamond, electronic asset or other items that are easy to be stored as well as items that do not appreciate in value over a certain period of time (Ismail \& Ahmad 1997). This will be other challenges to the Islamic pawnshops to diversify the items that can be pawned by the customers. From this, it will attract more customers to borrow from Ar Rahnu not only applicable to those who have the gold or jewellery but also to those who have a valuable asset that can be pawned.

Increase competition among the services providers in providing instant cash is being one of the challenges to Islamic pawn broking. Despite conventional pawn broking, illegal money brokers also be one of the competitors to the Ar Rahnu industry. They can offer loan to the customer with an easy way, not required to provide collateral to obtain cash and unlimited time to redeem (Bhatt, P., \& Lecturer, J. S. 2008).It is a reasons to the Ar Rahnu operators to create awareness to the consumers on the benefits of Islamic pawn broking and advisable to Ar Rahnu operators to impose lower safe keeping fees to the customers compared to conventional pawn broking. This can avoid them from obtain money from illegal money lenders which offer high interest and not transparent in the transaction.

\subsection{Conclusion}

In conclusion, based on the record of performance Ar Rahnu operators, it cannot be denied that Islamic pawned shops in Malaysia have a big potential in the society development that if the issues arise in islamic pawnshop activities can be solved. It is a fact that Islamic pawn broking system has the capacity and capability to fulfill the demand from customers and influence short term credit structure in the country. From the function to serve the needy or poorer to obtain cash and provide micro financing, currently Islamic pawn broking seem had demand from the medium and high level income customers. In the early of establishment of Ar Rahnu, customer pledge the gold and jewellery to obtain instant cash to support their daily life and their business but nowadays some customers pledge their asset to obtain loan to do investment. This scenario seems Islamic pawn broking have a potential growth in the future. For further growth it is necessary to the Ar Rahnu operators to handle the issue and challenge arise in a good manner and suggested that,all the Ar Rahnu Operations should maintain

their key strengths as an Islamic micro financing provider with free from riba, transparents in the transaction and lowest cost of borrowing compared to conventional pawn broking. The policy makers such as state government or federal goverment should supervise the operations of Ar Rahnu to ensure their operations is in line with the Shariah rules and emphasise on the social benefit to the customers instead of focusing on profit maximizing such conventional pawn broking.

\section{References}

Abdul Razak, A .(2011).Economic and Religious Significance of the Islamic and Conventional Pawnbroking in Malaysia. Behavioral and Perception Analysis.Durhan University

Abdul Ghafar Ismail and Nor Zakiah Ahmad.(1997). Pawnshop as an Instrument of Microenterprise credit in Malaysia. International Journal of Social Economics,bol 24.No.11.pp. 1343-1352

Azizah Othman,Norashidah Othman and Syahrina Abdullah.(2013).Perkembangan Ar Rahnu di

Terengganu: Kajian Kes Terhadap Ar Rahnu Majlis Agama Islam dan Adat Melayu Terengganu(MAIDAM). Prosiding PERKEM VII,vol 2,951-959.

Amin, H. (2011). Modelling Ar-Rahnu Use in Eastern Malaysia: Perspectives of Muslimah. Journal of Islamic Economics, Banking and Finance, 7(No.3, Jul-Sep 2011), 63-76. Retrieved from http://ibtra.com/pdf/journal/v7_n3_article4.pdf

Cheong,C.,\& Sinnakkannu,J.(2002).Ar Rahnu: Opportunities and Challenges in Malaysia. Available at SSRN:http://ssrn.com/abstract=2112809

Hanudin Amin,Rosita Chong,etl.(2007).Ar Rahnu Shop Acceptance Model(ARSAM).Labuan e- journal of Muamalah and Soceity.vol 1.pp.82-94

Imani Mokhtar \& Shah Rizal Zambahari.(2013).Ar rahnu: A Short Term Financing Alternative.

Proceeding Paper IECONS 2013.863-871

Ismail, A. G., \& Ahmad, N. Z. (1997). Pawnshop as an instrument of microenterprise credit in

Malaysia. International Journal of Social Economics, 24, 1343-1352. doi:10.1108/03068299710193633

Johari, M. N. S. Bin. (2013). Paper Proceeding of the 5th Islamic Economics System Conference

(iECONS 2013), "Sustainable Development Through The Islamic Economics System",

Lecturer, Bhatt, P., \& Lecturer, J. S. (2008). Ar-Rahnu (Islamic Pawning Broking) Opportunities and Challenges in Malaysia. 6th International Islamic Finance Conference 2008 Peer Reviewed Paper.

Muhammad saiful Islami,Siti Aisyah Yusof\& Norridzwan Abidin.(2010).Prinsip Al-Rahn Sebagai 
Asas Perlaksanaan Skim Pajak Gadai Islam Di Malaysia. Voice of Academia,vol 5.no.1.

Mohd Roslan M.N, Ahmad Termizi A. etl.(2012).Historical Development of Islamic institutions:

A case

of Malaysian Government. African Journal of Business Management. Vol 6(8),pp.2766-

2772.

Mohamad A.H.,Ishak A.R., \& Ahmad Nafis A.H(2014).Factors Affecting the Acceptance on Ar

Rahnu : A Case Study of Islamic Banking in Malaysia.The Macrotheme Review 3(4),Spring.

Norhaziah Nawai \& Mohd Nor Mohd Sharif.(2010).Determinants of Repayment Performance in Microcredit Programs: A review of Literature.

Othman, A., Hashim, N., \& Abdullah, S. (2012). Satisfaction Levels Of Service Quality At Ar-Rahnu, Kelantan. 3rd International Conference On Business And Economic Research3rd ICBER 2012) Proceeding, (March), 30213030.

S.A. Bashir Ahmad, Norudin Mansor and A. Nurul Nadiah . (2012). Customer Acceptance on
Islamic Pawn Broking: A Malaysian Case. Interdisciplinary Journal of Contemporary Research In Business,vol 3,10, 751-763.

S.Hisham,S.Abdul Hukor,A.B.Ummi Salwa and Kamawuzaman Jusoff.(2013).The Concept and

Challenges of Islamic Pawn Broking (Ar Rahnu). Journal of Scientific Research 13,98- 102.

Skully, M. T. (1992). The Development of the Pawnshop Industry in East Asia. East Asia.

Saiful Islami, M.T., Corresponding,Siti Aisyah .,Y, S. A., \& Abidin, N. (2010). Prinsip Al-Rahn Sebagai Asas Pelaksanaan Skim, 5(1), 1-16.

Sharif, D., Shaharuddin, A., Muhamed, N. A., Pauzi, N. S., \& Mohd, M. Z. (2013). The Improvement of Ar-Rahn ( Islamic Pawn Broking ) Enhanced Product in Islamic Banking System, 9(2), 36-47. doi:10.5539/ass.v9n2p36 